\title{
Gravimetric survey and modeling of the basement morphology in the sedimentary thickness characterization, NE portion of Paraná Sedimentary Basin - Brazil
}

Aquisição gravimétrica e modelagem da morfologia do embasamento na caracterização da espessura sedimentar, porção NE da Bacia Sedimentar do Paraná - Brasil

\author{
Maximilian Fries ${ }^{1 *}$, Walter Malagutti Filho ${ }^{2}$, \\ João Carlos Dourado², Mariana Aparecida Fernandes ${ }^{3}$
}

\begin{abstract}
The northeast portion of the Paraná Sedimentary Ba$\sin$ is distinguished by structural highs as the known Pitanga Dome, an uplifted structure identified in the last century. It represents a geological and evolutionary evidence of the Paraná Sedimentary Basin and has undergone inspired studies and intense exploration surveys. This study consists of a gravimetric survey in the Pitanga Dome area, State of São Paulo, Brazil. The Bouguer gravity anomalies have been identified and related to the structural high, sedimentary thickness, and the basement morphology. Processing and enhancement techniques were used for forward modeling based on previous studies. The three models from profiles sectioning the dome have a sedimentary thickness varying from 200 to 1.250 meters. The adopted methodology has provided important results determining that the Pitanga Dome can be understood through rational $3 \mathrm{D}$ visualization. The area can be interpreted as an undulating basement with thinning of sedimentary rocks related to deep features (structures) in the crust/ mantle limit (Moho uplift). This characteristic is confirmed by the sedimentary layer thickening present throughout the surrounding area. The results also offer important insights and support for further studies concerning the genesis and evolution of this and other uplifted structures of the Paraná Sedimentary Basin.
\end{abstract}

KEYWORDS: Paraná basin; Gravimetry; Modeling.
RESUMO: A porçāo nordeste da Bacia Sedimentar do Paraná distingue-se pelos altos estruturais e o conhecido Domo de Pitanga, uma estrutura de soerguimento identificada no século passado. Representa uma evidência geológica e evolutiva da Bacia Sedimentar do Paraná sendo alvo de diversos estudos e pesquisas de exploração. Este estudo consiste em uma aquisição gravimétrica na área do Domo de Pitanga, Estado de São Paulo, Brasil. As anomalias Bouguer são relacionadas com o alto estrutural, espessura de sedimentos e morfologia do embasamento. Técnicas de processamento e realce foram usadas para modelagem direta com base em estudos anteriores. Três modelos foram gerados em perfis seccionando o domo e apresentam espessuras de sedimentos variando de 200 a 1.250 metros. A A metodologia adotada forneceu importantes resultados estabelecendo o entendimento através da visualização 3D racional do Domo de Pitanga. A área pode ser interpretada como uma ondulação do embasamento com afinamento na espessura dos sedimentos associado a estruturas em profundidade no limite crostalmanto (soerguimento da Moho). Esta característica é confirmada pelo espessamento das camadas sedimentares em toda área circundante. Os resultados também fornecem importantes subsidios e apoio a novos estudos sobre a gênese e evolução deste e de outros altos estruturais na Bacia Sedimentar do Paraná.

PALAVRAS-CHAVE: Bacia do Paraná; Gravimetria; Modelagem.

\footnotetext{
${ }^{1}$ Associate Professor, Laboratório de Geofísica Aplicada, Universidade Federal do Pampa - UNIPAMPA, Caçapava do Sul (RS), Brazil. E-mail: maximilianfries@unipampa.edu.br ${ }^{2}$ Associate Professor, Departamento de Geologia Aplicada, Instituto de Geociências e Ciências Exatas, Universidade Estadual Paulista "Júlio de Mesquita Filho" UNESP, Rio Claro (SP), Brazil. E-mails: malaguti@rc.unesp.br, jdourado@rc.unesp.br

${ }^{3}$ Geologist, Geociences PhD, Departamento de Geologia Aplicada, Instituto de Geociências e Ciências Exatas, Universidade Estadual Paulista “Júlio de Mesquita Filho” UNESP, Rio Claro (SP), Brazil. E-mail: mafer@rc.unesp.br

*Corresponding author.
}

Manuscript ID: 20160117. Received in: 10/03/2016. Approved in: 02/20/2017. 


\section{INTRODUCTION AND OBJECTIVES}

In recent decades, important studies at a regional scale analyzed and characterized the geological and structural context of the Paraná Sedimentary Basin and its relation to the origin and development of the South American platform Fulfaro (1971), Fulfaro et al. (1980, 1982), Almeida (1980), Ferreira et al. (1981), Ferreira (1982), Soares et al. (1982), Cordani et al. (1984), Zalán et al. (1987, 1990), Soares (1991), Quintas (1994) and Milani (1997).

Such studies were driven and sponsored due to the desire, at the time, to discover and define potential hydrocarbon producing areas. In a period of development of alternative fuels across the world, and the oil crisis in the 1970's, the newly created Consortium CESP-IPT/Paulipetro caused an intense mobilization of geoscientists. Then, a period of geological and geophysical surveys and research on a regional scale in the Paraná Sedimentary Basin were funded (IPT 1980, 1981, Paulipetro 1981).

This consortium provided an opportunity to explore viable and economic target areas in the Paraná Basin (Paraná, Santa Catarina and São Paulo States). Potential areas were identified, analyzed and characterized, resulting in a great improvement in the knowledge of the evolution of the geology and structure of the basin. Domains and structural lineaments were outlined and identified through magnetometric, seismic and electrical resistivity surveys.

In this context, structural highs in the northeastern portion of the basin were identified. These potential hydrocarbon reservoir structures, located near Piracicaba and Rio Claro, São Paulo, Brazil, are known as Pitanga, Artemis, Pau D'Alho and Jibóia. The Pitanga structure, first recognized by Washburne (1930), is identified and recognized as a dome shaped structure, being also a peculiar and interesting structure as an exploration target then and until the present day as an important reward and feature of the basin evolution studies.

The choice and purpose of this study were strongly influenced by studies of Soares (1971, 1973), Soares and Landim (1973), Bósio (1973), Castro (1973), Souza Filho (1983), Hasuiu et al. (1989), Landim et al. (1980), Morales et al. (1997), Riccomini (1989, 1992, 1995, 1997), Rostirola et al. (2002) and Dourado (2004). Among these studies, Sousa (1997) and Sousa (2002) detailed the geology and structural framework, as well as a refined characterization of lineaments and limits of the Pitanga Dome, which served as the main motivation to refine this structure. The goal of this work is to use regional gravity data constrained by geological and previous geophysical data to determine the basement morphology, defining the higher and lower areas of the Precambrian basement (sedimentary thickness), based on forward 2.5D modeling.

The study area is located in the Sáo Paulo State, middle-eastern part and northeast flank of the Paraná Sedimentary Basin. The region comprises the known structural uplifts of Pitanga, Artemis, Pau D'Alho, and Jibóia, and it covers an area of $4,000 \mathrm{~km}^{2}$. Their main cities are Rio Claro, Piracicaba, São Pedro and Águas de São Pedro (Fig. 1).

\section{PARANÁ SEDIMENTARY BASIN: EVOLUTION AND GEOLOGICAL SETTING}

The Paraná Sedimentary Basin has an area of about 1.2 million $\mathrm{km}^{2}$ and comprises the southern part of Brazil, the eastern half of Paraguay, the Mesopotamian region of Argentina, and the western half of Uruguay. The basin has an elongated shape to NNE-SSW directions, approximately $1,700 \mathrm{~km}$ long, with an average width of $900 \mathrm{~km}$ (Zalán et al. 1990). It presents basaltic lava flows in two-thirds of Brazil's portion, reaching up to $1,700 \mathrm{~m}$ thick which, adding the sills, comprises up to 2,000 m thick of igneous rocks. The maximum thickness of sedimentary and volcanic rocks is around $8,000 \mathrm{~m}$ at the geometric center of the basin (Zalán et al. 1987) (Fig. 2).

Its present location is a response to Mesozoic/Cenozoic orogenic events, and its axis would have migrated over time, probably from west to east. The rock packages of the South America convergent margin generated a flexural arch located farther inland of the continent during compressional and sedimentary processes. Zalán et al. (1987) argues that in the main Paraná Basin alignments there is a strong pattern in these linear features (X form). These features can be divided into three groups, according to its NW-SE, NE-SW and E-W direction.

The two most important trends are NW-SE and NE-SW, which can be simple or extensive fault zones (hundreds of kilometers long and a few tens of kilometers wide). These two groups of tectonic elements are old zones of weakness, which were recurrently active during basin evolution.

This same pattern of tectonic elements (NW-SE and NE-SW) is recognized by Soares et al. (1982) in a detailed study of Landsat images and radar of central and eastern parts of the basin. These authors argue that these structural zones represent areas with major tectonic mobility compared to adjacent areas. Several of these "mobile parts" coincide with those that have been mapped and described by authors, based on aeromagnetic data (Zalán et al. 1987), who also concluded that these elements represent basement weakness zones, and several of them controlled sedimentation during 
the evolution of the basin, and the areas with NW trend are intensively intruded by diabase dykes, while NE trends are remarkably devoid of these features. Zalán et al. (1990) showed that NW-SE and NE-SW trends occurring across the basin also confirmed the existence of a third important lineament group with an E-W direction.

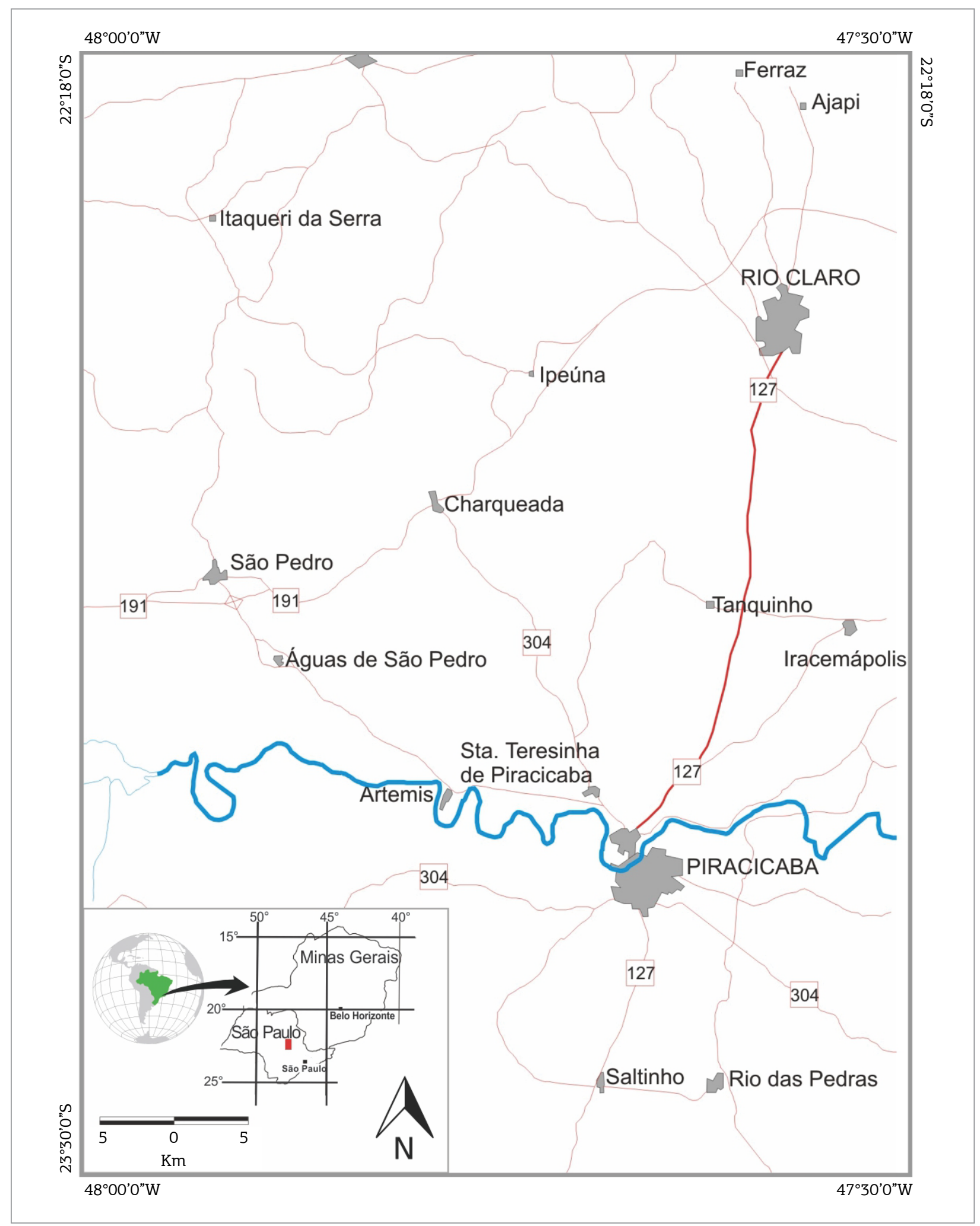

Figure 1. Location map of the study area, main highways, access roads, and cities. 


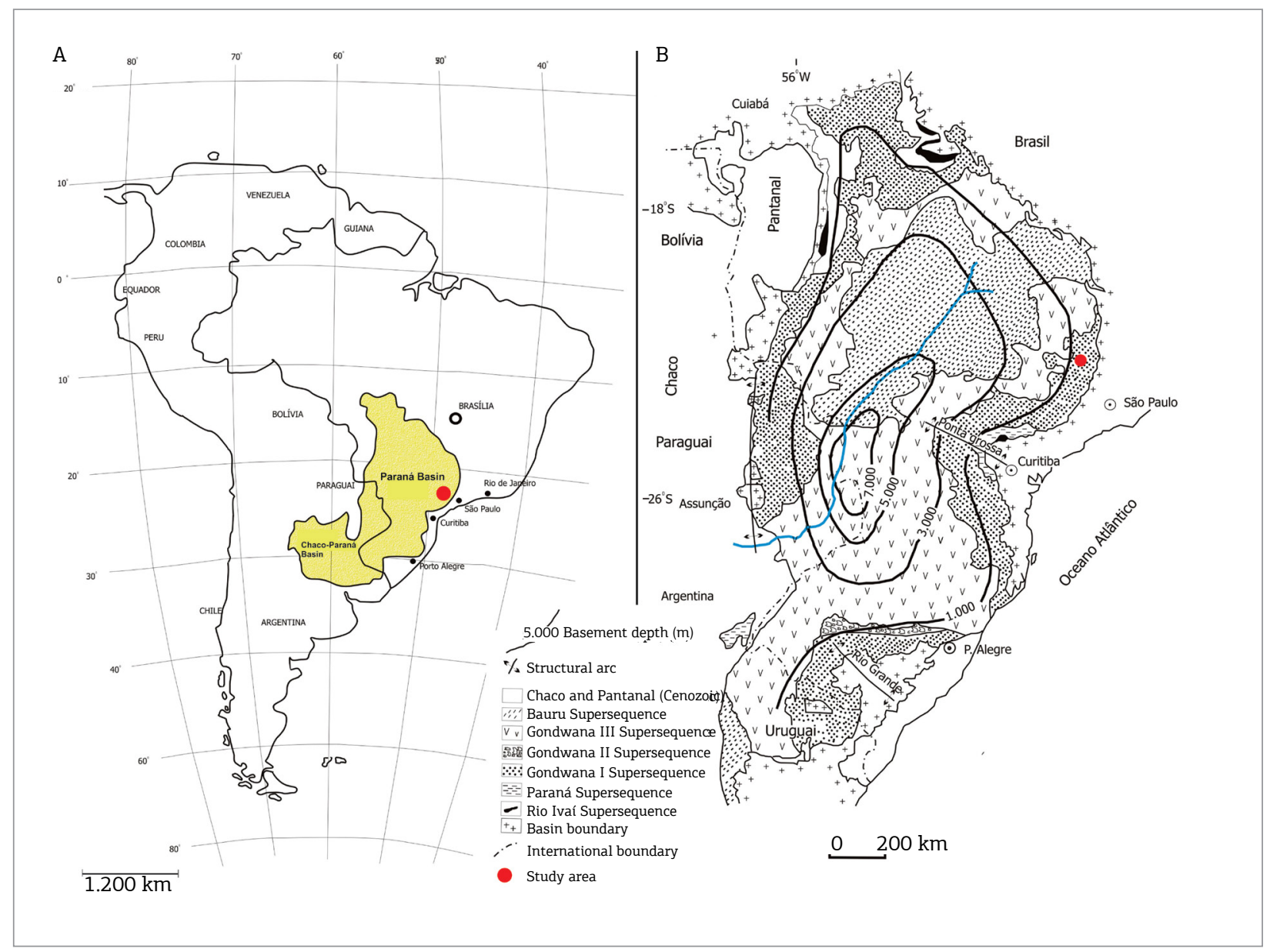

Figure 2. (A) The Paraná Sedimentary Basin within the South American Continent and study area location (red dot); (B) Paraná Basin simplified geological map, geographic references, basement depth, and study area (red dot). Adapted and modified from Zalán et al. (1990) and Milani \& Ramos (1998).

\section{Study Area: Geological and Structural Setting}

The age of the rocks that compose the geological setting in the area vary from Carboniferous to Permian (Itararé Group, Tatuí Group and Irati Formation); Upper Cretaceous including the basaltic lava flows intruded within the sedimentary rocks, Pirambóia, Botucatu and Itaqueri Formations; and the Neocenozoic sediments present in the flatter regions in the basin (Fig. 3A). These rocks units and their related Groups and Formations are described in detail by Soares and Landim (1973), Soares (1974), Riccomini (1992), Sousa $(1997,2002)$.

In terms of structural characterization, Soares (1974), and more recently Sousa $(1997,2002)$, recognized the fault system in Passa Cinco - Cabeça and Ipeúna - Piracicaba. The tectonic and structural framework in the area is conditioned through the stratigraphic units distribution as uplifted, tilted and mainly controlled by faulting. In this way, the younger units emerge side by side the older ones.
Rocks layer inclinations generally gently present $2^{\circ}$ to $5^{\circ}$ dip, although locally, dip values can be higher, reaching $75^{\circ}$ related to the fault limited blocks. According to the known lineaments (Fig. 3B), the area is strongly influenced by lineaments oriented in NW, EW and NE directions that are related to the normal faults. The NW-SE direction fault bundle is characterized by tilted blocks, conditioning the structural uplift geometry from Pitanga, Artemis, Pau D’Alho, and Jibóia.

Sousa $(1997,2002)$ argue that the array and structural subdivision (compartmentation) from these structural highs are associated with the stratigraphic units, and block movements are controlled by faulting, considering that the recent units juxtapose older rocks units.

The morphotectonics in the area can be described as a distensional regime, producing the normal faults generation (NE-SW) directly related to the Gondwana partioning, as well as a strike-slip fault regime that reactivated previous discontinuities, probably fault zones originating in the basement. 


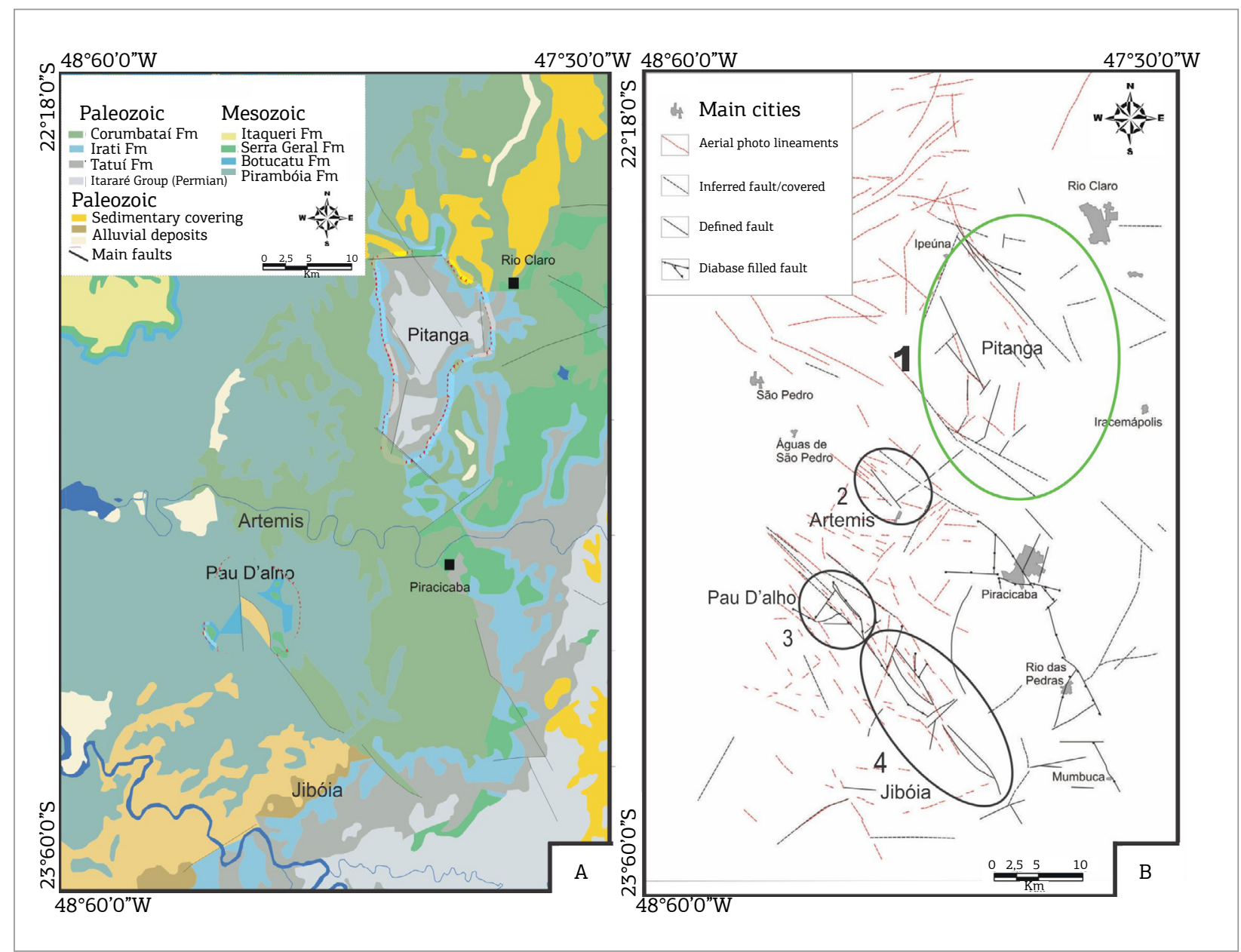

Figure 3. (A) Main geological units and structural uplifts located in the Paraná Basin NE portion according CPRM (2001); (B) lineaments recognized according to Sousa (2002) and Pitanga Dome location in the area (green ellipse 1) and Artemis (2), Pau D'Alho (3), and Jibóia (4) minor structural highs.

\section{METHODS}

\section{Gravimetric Survey and Data Processment}

For gravimetric data acquisition, a La Coste Romberg model G, number 987 — was used. The equipment belongs to the Applied Geology Department from São Paulo State University (IGCE/UNESP), Rio Claro, São Paulo.

The relative gravity measurements and the absolute gravity values were tied to the International Gravity Standardization Network (IGSN71) using the absolute Base Station from the Secondary Gravity Network from Sáo Paulo State (Rede Gravimétrica Secundária do Estado de São Paulo), deployed by the Geophysics Department of São Paulo University (IAG/USP). Both the secondary gravimetric — in the State of São Paulo — and the Brazilian Fundamental Networks are referenced to IGSN71. The base station is located in downtown Rio
Claro at Latitude $22^{\circ} 24.63^{\prime} \mathrm{S}$ and Longitude $47^{\circ} 33.67^{\prime} \mathrm{W}$. The altitude is $624 \mathrm{~m}$.

The gravity data, which totaled 595 stations, have an average station spacing of $2 \mathrm{~km}$ and were acquired along major highways, local roads and accesses. All the data were merged and reduced using the 1967 International Gravity Formula. Free Air and Bouguer gravity corrections were made using sea level as a datum and $2.67 \mathrm{~g} / \mathrm{cm}^{3}$ as a reduction density. Corrections and data reduction processing (latitude, tide, drift, free-air and terrain corrections) were performed using the Oasis montaj software, GEOSOFT Inc. - Gravity toolkit.

Gravity station georeferencing was achieved using a precision GPS receiver according to the data differential correction technique (DGPS) to minimize the reference ellipsoid/ topography difference error (Fairhead \& Odegard 2002, Fairhead et al. 2003).

As a way of monitoring the process, the positioning and altimetry were compared with topographic maps 
(1:10,000 scale) from the Geographic and Cartographic Institute of São Paulo (Instituto Geográfico e Cartográfico de São Paulo - IGC), and Altitude Reference Stations (Referência de Nivel - RNs) from Instituto Brasileiro de Geografia e Estatistica (IBGE) located in the survey area. The coordinates and elevations were acquired using a Trimble GPS receiver (model: Pathfinder ProXR), with an accuracy GPS receiver, with nominal horizontal precision of $0.005 \mathrm{~m} \pm 1 \mathrm{ppm}$, and vertical accuracy of $0.01 \mathrm{~m} \pm 2 \mathrm{ppm}$. For Rover data acquisition in the field, the TerraSync (Trimble Inc.) software was used.

For the post-correction processing, a GPS base station was used, comprising the DGPS Network from Santiago \& Cintra Geotechnologies Company, and was located in the IGCE/UNESP, Rio Claro, São Paulo. The Base Station files and Rover files (GPS data survey) were corrected using the Pathfinder software. The average time of GPS rover data acquisition for the measured gravity station was $15 \mathrm{~min}$, with a maximum of $20 \mathrm{~min}$.

\section{Gravimetric Maps}

The Bouguer anomaly map (Fig. 4A) was generated using the Oasis montaj software with the minimum curvature interpolation method (Briggs 1974). With a regular grid of $77 \mathrm{X} 97$ points (X and Y respectively) and 1,000 X 1,000 m grid cell size, respecting the minimum value of one fourth of the observation station data spacing. The coordinate system used in the maps is the Universal Transverse Mercator (UTM), Zone 23 South. The reference ellipsoid South American Datum (SAD 69) was adopted respecting the cartographic system from previous geological and geophysical studies (CPRM 2001, IPT 1980).

\section{RESULTS}

\section{Gravimetric Data Analysis}

\section{Semi-Quantitative Analysis}

Causative source depths from gravimetric data and frequency analysis were obtained by converting the original grid from spatial to frequency domain, by using the Fast Fourier Transform (FFT) technique (Cordell $\&$ Grauch 1982). The frequencies and related source depths according to frequencies are displayed in the Radially Averaged Power Spectrum (Spector \& Grant 1970, Ofoegbu \& Hein 1991, Cowan \& Cowan 1993, Hildenbrand \& Kucks 1983).

Spectral methods have been commonly used in the analysis of potential field data to provide first-order depth estimates to density and magnetic susceptibility interfaces (for example, Dorman \& Lewis 1970, Shuey et al. 1977, Tselentis et al. 1988, Blakely 1988). The spectral method assumes that the density or magnetic susceptibility boundaries are essentially horizontal interfaces.

The calculated results represent the log of Radial Power Spectrum of gravity potential field as a function of wave number/frequency $(1 / \mathrm{km})$. The depth estimates are used to constrain gravity/magnetic source solutions, allowing the separation of shallow, intermediate and deep sources depth from the gravity data. This analysis consists of a semi-quantitative technique for causative sources (magnetic and gravimetric), and is interpreted in the frequency domain.

To estimate spectrally determined depths, a radially averaged $2 \mathrm{D}$ power density spectrum is calculated over a region. In this case, we used the Bouguer anomaly results (Fig. 4B).

After analysis of the plot representing the radial average of the energy spectrum versus the radial frequency, we can determine three major segments and their respective slopes. The energy spectrum exhibits three linear equivalent source depths:
- Deep basement sources;
- Intermediate basement sources;
- Shallow sedimentary sources.

In order to enhance the gravimetric anomalies (deeper features of interest), Radially Averaged Power Spectrum analysis and cut-off frequency values (Band Pass filter) were applied. In this manner, a deep source Bouguer gravity anomaly map was generated. For the purpose of this study, cut off values of 0.01 and 0.11 (minimum and maximum) — denominated here as Band Pass Filter - Deep Sources Anomalies - were generated according to Fig. 4C. Considering the lithologies and structure limits, three profiles (Fig. 4D) sectioning the main anomalies of interest related to the uplifted area (structural high - Pitanga Dome) were determined for the 2.5D gravity modeling.

\section{Quantitative Analysis: Gravity Modeling}

The geophysical forward modeling in this study was performed using the software GM-SYS, a toolkit within the Geosoft Oasis montaj platform. The model calculates theoretical responses of a pre-designed geological model based on the known geology and basement depths from earlier studies, and comparing the responses to observed gravimetric data.

A 2.5D modeling of selected profiles is displayed according to a number of rectangular prisms, whose major axes are aligned with the main direction (strike) of a particular structure or feature (defining the $\mathrm{X}$-axis). The profile bisects an interest structure of features and correlated anomaly 
(Z-axis). Perpendicular to the main direction determined for the model (strike) is the Y-axis that can be changed, directly influencing the response of the calculated final curve. Considering the regional nature of this study, the length of the Y-axis was set to infinity for the modeled prisms - both for crust and sediments. Considering the local geological context, for the basic rocks, the length was adjusted to a maximum of $10 \mathrm{~km}$.

The algorithm used in order to calculate the response of gravity models is described by Talwani et al. (1959), Talwani \& Heirtzler (1964) and GM-SYS (2000). The direct-modeling average density values used in this study were determined

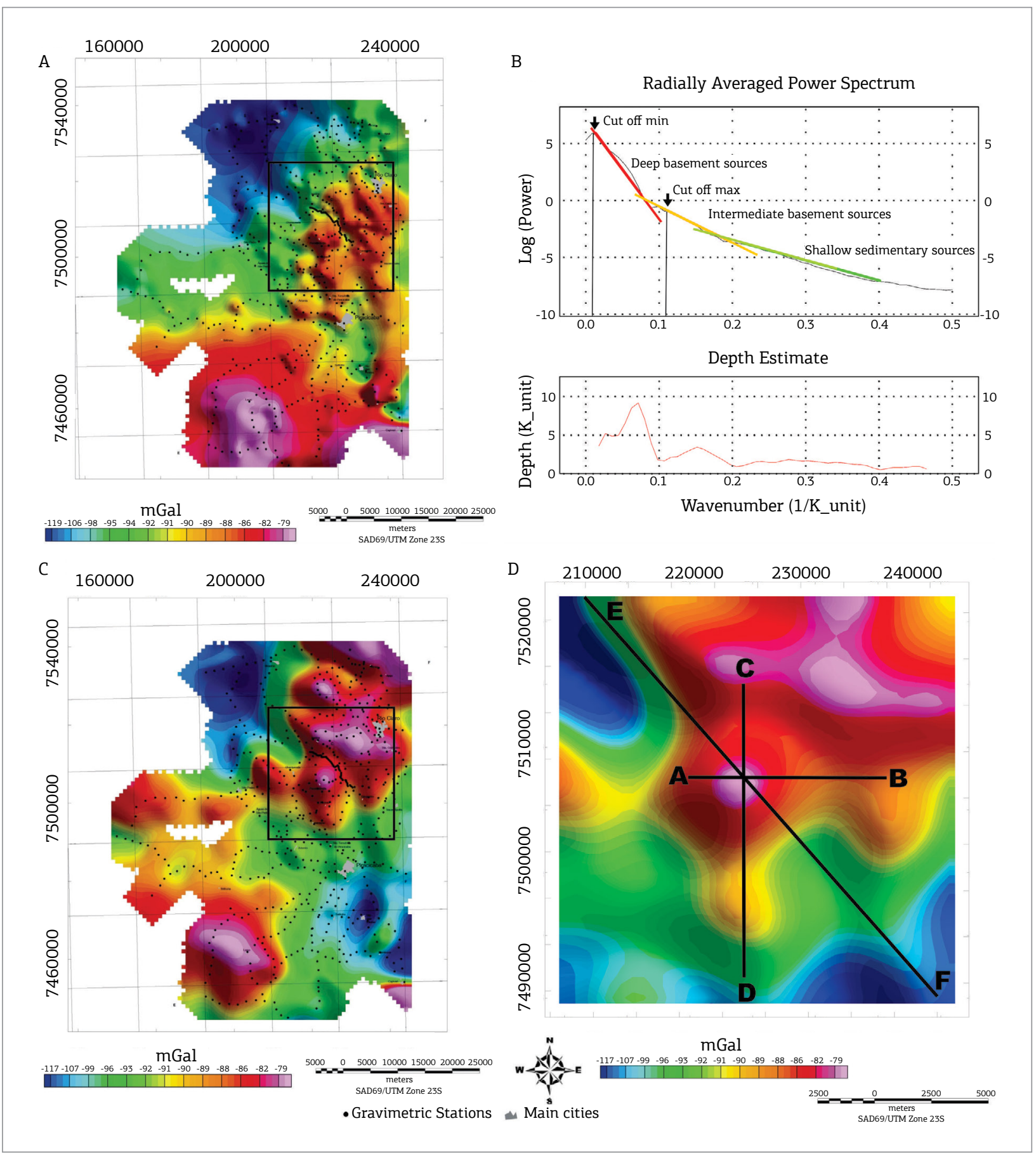

Figure 4. Shaded relief Bouguer anomaly maps (45 azimuth and $45^{\circ}$ inclination) and Pitanga structural high uplift area limits (black rectangle): (A) Bouguer anomaly map and gravity stations; (B) Semi-quantitative analysis, anomalous sources depth (RAPS); (C) Bouguer anomaly map, Band Pass Filter - Deep Sources and Pitanga Dome limits (black rectangle); (D) Pitanga Dome detailed map with selected profiles used for gravity forward modeling. 
according the mean density values from igneous and sedimentary rocks from Telford et al. (1990) (Tab. 1).

Models A-B (Fig. 5) and C-D (Fig. 6) are proposed from two profiles sectioning the Pitanga Dome.

The profile E-F, a cross-section throughout the entire gravimetric survey area (NW-SE strike direction), was chosen to obtain a visualization and characterization of the influence of surrounding rocks near the uplift structure of Pitanga Dome (a regional feature), as shown in Fig. 7.
Table 1. Geophysical modeling density values used in this study. Mean values are from Telford et al. (1990) for sedimentary, basic and basement rocks.

\begin{tabular}{l|c}
\hline Model Lithology & Density $-\mathbf{g} / \mathbf{c m}^{\mathbf{3}} \mathbf{( S I )}$ \\
\hline Paraná Basin Sediments & 2.4 \\
\hline Basic rocks & 2.85 \\
\hline Basement & 2.67 \\
\hline Upper/Lower Crust & 2.80 \\
\hline Mantle & 4.0
\end{tabular}

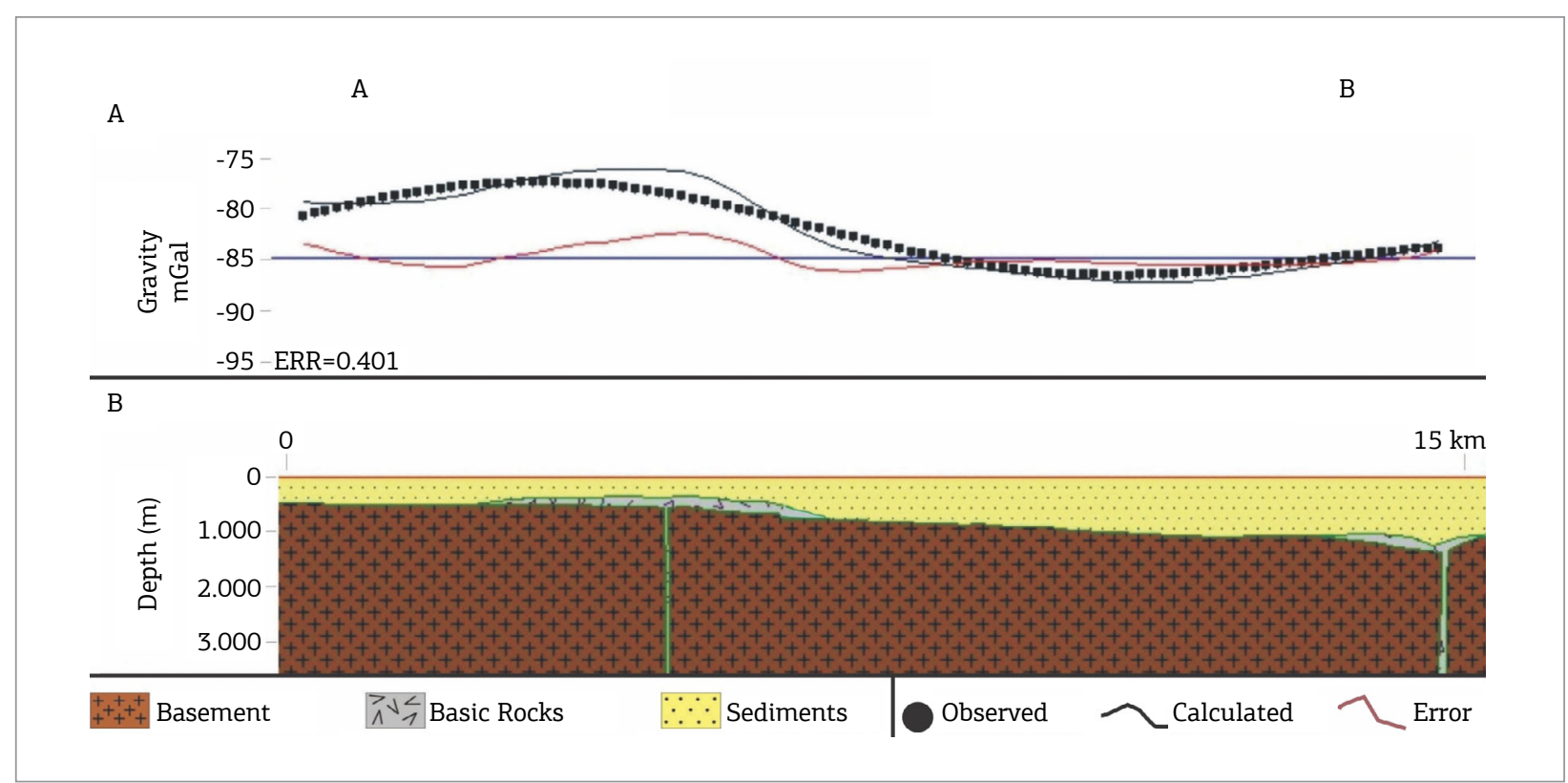

Figure 5. W-E direction modeled profile A - B in the structural area (Pitanga Dome). (A) Observed gravity data, calculated curve and adjustment (error). (B) Crustal modeling with sediments and basic rocks.

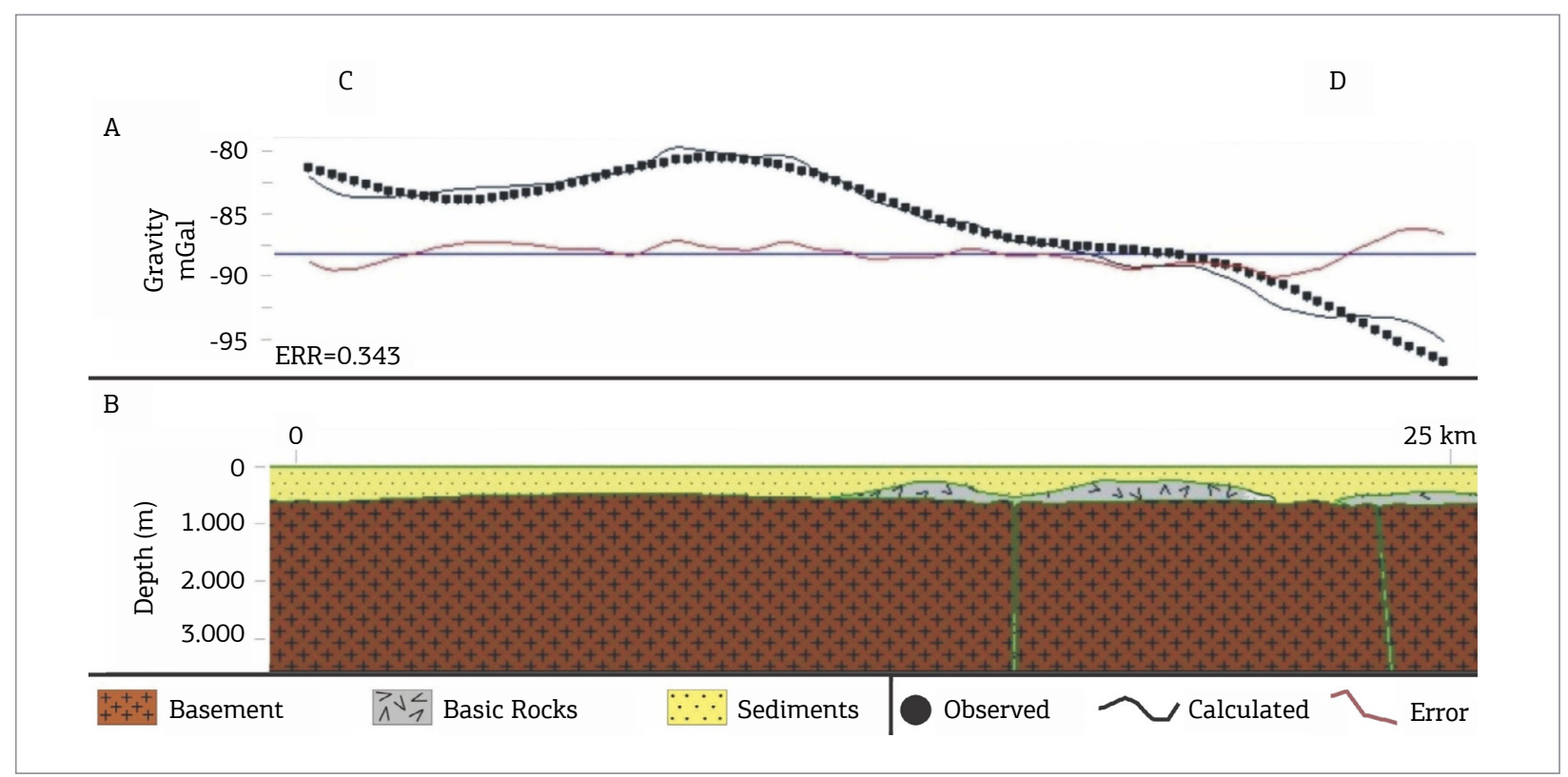

Figure 6. N-S direction modeled profile C - D in the structural high area (Pitanga Dome). (A) Observed gravity data, calculated curve and adjustment (error). (B) Crustal modeling with sediments and basic rocks. 


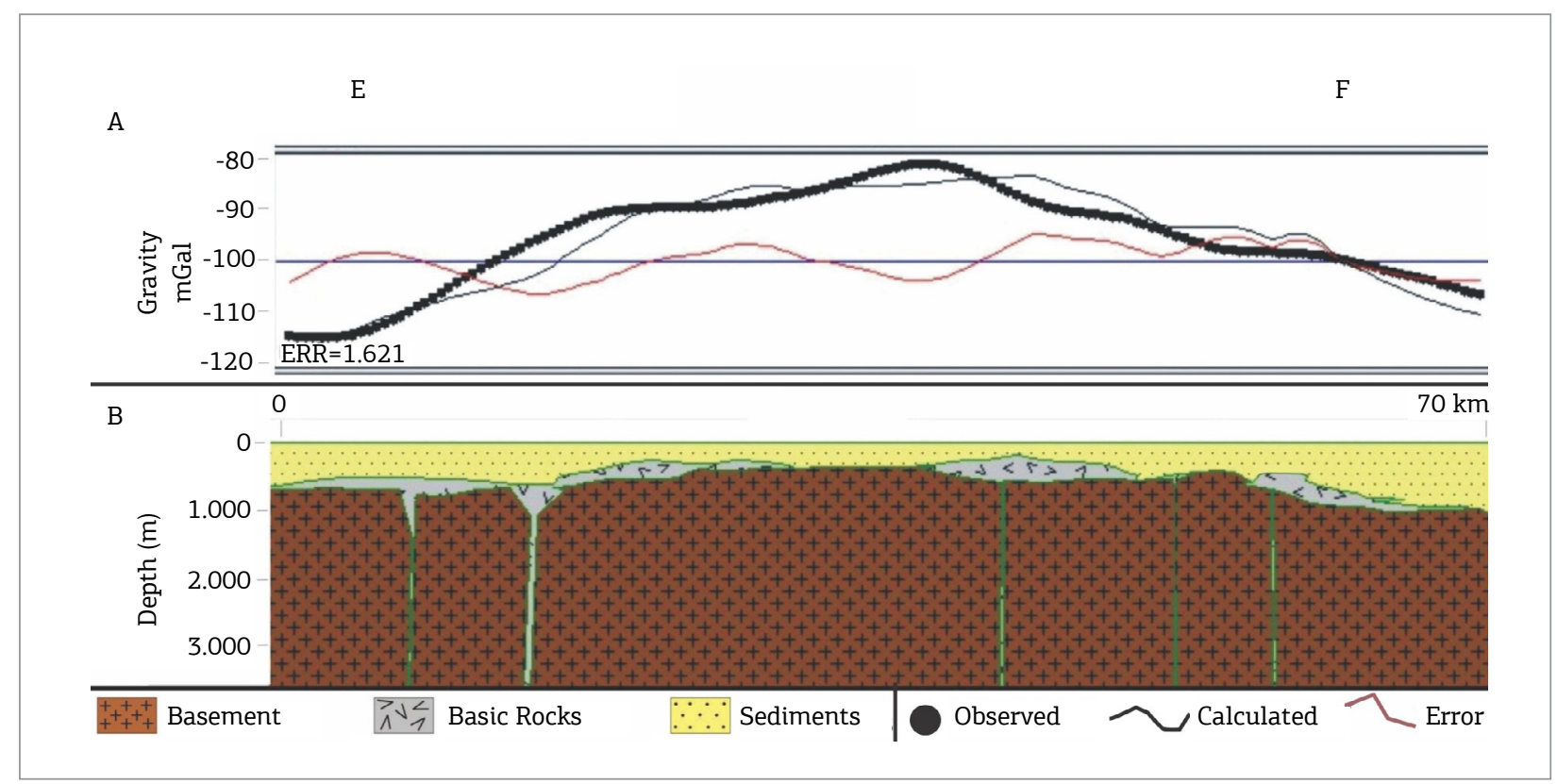

Figure 7. Modeled profile E - F in the structural high area (Pitanga Dome). (A) Observed gravity data, calculated curve and adjustment (error); (B) crustal modeling with sediments and basic rocks.

\section{DISCUSSIONS}

Previous studies in the Paraná Sedimentary Basin argue that sediment thickeness in the center of the basin can reach $8,000 \mathrm{~m}$ in the northeast portion of the basin and, according to isopach maps (Milani \& Ramos 1998), the depths are 1,000 to $2,000 \mathrm{~m}$ in the region near the basement (studied area). Considering this, the forward generated models from the observed gravimetric responses relied primarily on these geological and structural results recognized in published studies and also in recent local studies on and nearby the proposed area (Riccomini 1992, Sousa 1997, 2002).

However, geophysical results are important benchmarks in the quantification of physical parameters of the rock packages and actual thicknesses, considering that deep drilling soundings, deep water wells, seismic and other crustal studies were not performed in the area.

Basement and sediment depth-limit parameters in the forward gravity modeling, obtained using the Band Pass Filter - Deeper Sources from the observed gravity data, are coherent and supported when compared to the previous geophysical studies performed by IPT (1980) and Dourado (2004). These previous information also helped to reduce interpreter bias during model generation.

The seismic receiver function method (Dourado 2004) indicates that the crust-mantle depth limit varies approximately $38 \mathrm{~km}$ to the $\mathrm{SW}$ and $43 \mathrm{~km}$ for the azimuth N $168^{\circ}$ in the Pitanga Dome area. The decrease in depth to the SW, associated with the tangential Receiver Function analysis shows a NE dip, suggesting that the structural high
(Pitanga Dome) has its origin in deep phenomena, which also affected the crust/mantle interfaces and the structural pattern in different tectonic phases. This same azimuth analysis indicates a thickening of the basin sediments to the west, where the thickness of the sediments may exceed $1 \mathrm{~km}$ in some areas.

IPT (1980) in DC resistivity (Vertical Deep Sounding technique) and magnetometric surveys in São Pedro and Piracicaba region have distinguished the crystalline rocks from basement and provided information about the overlaying sedimentary rocks and structural framework in deeper levels. It has also provided a morphological understanding in the covered area. Near Piracicaba and São Pedro, the sedimentary units have an average thickness of $1,000 \mathrm{~m}$. In the area, which extends up to Charqueada city and Piracicaba River, the thickness of this sediment cover reaches up to $1,472 \mathrm{~m}$.

The basement depth and morphology results, calculated using the DC Vertical Deep Soundings, provide a sedimentary contour map where the highest basement areas (thinner sediments coverage) are $500 \mathrm{~m}$ deep (studied area) and the lowest ones (thicker sediments coverage) reach $952 \mathrm{~m}$, getting deeper toward northeast.

A significant discrepancy between observed and calculated curves is seen in some parts of the forward generated models (Figs. 5 and 7). These discrepancies reflect the chosen approach of use the horizons from previous geophysical studies as tie depths to define the limits of crust/sediments in the forward modeling. In this case the adjustment parameter accuracy played a secondary role considering that the generated models should fit in the geological context and 
not only an observed versus calculated curve adjustment. A concentrated presence of intruded basic rocks (Serra Geral Formation), exhibiting different shape geometries (batholiths, sills and dikes) within the sediments, represents a noise source and complicating factor with regards to an ideal fit. This presence of high density material produces intense higher frequency anomalies in the shallower and deeper zones of the investigated area.

These characteristics, considering the high responses from gravimetric sources, represent spurious noise for the proposed study (Fries 2008). Lower magnitude source rocks anomalies (residuals) or high frequencies were also analyzed using the fourth normal form (4Fn) applied to the raw data. The analysis showed the presence both for the high frequencies raw data generated directly from the survey and the fourth difference calculated in the database. Considering these characteristics, deeper anomalies or lower source frequencies were used. It represents the regional anomalies or regional sources, which are the main object of analysis and interpretation for the modeled profiles.

\section{CONCLUSIONS}

In this paper we applied recognized and widely used geophysical acquisition methods and data processing/interpretation techniques both for geological mapping and for a better understanding of basement morphology by using indirectly obtained depth information associated with previous geological and geophysical studies in the region.

The generated gravity anomaly map present features related to the geologic and structural context in the area. Considering the limitations of the gravity method applied to such sources, such as lateral and depth lithologic and stratigraphic variations, unconformities, non-conformities and small scale intrusions, the results considering the main objective, were satisfactory.
The geophysical forward modeling sectioning the structural high (Pitanga Dome) adopting the Band Pass - Deeper Source Anomalies method to observed data allowed coherent assessment, correlation and analysis for comparing the different anomaly features observed in the Bouguer anomaly map. The sediment depth limits and basement morphology adopted for the generated model are also coherent and respect the limits recognized in previous studies.

Based on the results of gravity analysis using the Radial Power Spectrum, the Bouguer anomaly map and Band Pass - Deeper Sources Anomalies and 2,5D gravity forward modeling along three profiles (N-S, E-W and NW-SE), the Pitanga Dome can be understood in a rational $3 \mathrm{D}$ visualization. The area can be interpreted as an undulating basement with thinning of sedimentary rocks related to deep features (structures) in the crust/ mantle limit (Moho uplift). This characteristic is confirmed by the sedimentary layer thickening present throughout the surrounding area.

The proposed method also provides a better overview of the structural framework, gaps in understanding and support for further studies about this structural high (Pitanga Dome) and other similar structures in the eastern portion of the Paraná Sedimentary Basin.

\section{ACKNOWLEDGEMENTS}

The authors would like to thank: Fundação de Amparo a Pesquisa do Estado de São Paulo (FAPESP) process 04/00235-9, Francisco Barreira (Paco) (in memorian) for the field survey support, and Marieli Machado Zago for helping in map editing. We also thank the Applied Geology Department (Departamento de Geologia Aplicada) from the São Paulo State University (UNESP) - Campus Rio Claro, São Paulo — for all the support (equipment and vehicles).

\section{REFERENCES}

Almeida F.F.M. 1980. Tectônica da Bacia do Paraná no Brasil. Instituto de Pesquisas Tecnológicas do Estado de São Paulo. São Paulo: IPT. 187 p. Relatório 14.091.

Blakely R. 1988. Curie temperature isotherm analysis and tectonic implications of aeromagnetic data from Nevada. Journal of Geophysical Research, 93(10):11817-11832.

Bósio V.J. 1973. Geologia da área de São Pedro, SP. PhD Thesis, Faculdade de Filosofia, Ciências e Letras de Rio Claro, Rio Claro, 125 p.

Briggs I.C. 1974. Machine Contouring Using Minimum Curvature. Geophysics, 39(1):39-48.
Castro P.R.M. 1973. Contribuição ao estudo da estrutura do Pau d'Alho (Piracicaba, SP). PhD Thesis, Faculdade de Engenharia de Limeira, Universidade de Campinas, Campinas, 87 p.

Cordani U.G., Brito Neves B.B., Fuck R.A., Porto R., Thomaz Filho A., Cunha F.M.B. 1984. Estudo preliminar de integração do Pré-Cambriano com os eventos tectônicos das bacias sedimentares brasileiras. Rio de Janeiro: PETROBRAS. 70 p. Série Ciência - Técnica - Petróleo, Seção: Exploração de Petróleo da Petrobras.

Cordell L. \& Grauch V.J. 1982. Reconciliation of the discrete and integral Fourier transforms. Geophysics, 47:237-243. 
Cowan D.R. \& Cowan S. 1993. Separation filtering applied to aeromagnetic data. Exploration Geophysics, 24:429-436.

CPRM - Serviço Geológico do Brasil. 2001. Mapa geológico do Brasil, escala 1:2.500.000. In: Bizzi L.A., Delgado I.M., Abram M.B., Leão Neto R., Matos G.M.M., Santos J.O.S. Geologia, Tectônica e Recursos Minerais do Brasil: Sistema de Informacões Geográficas - SIG e Mapas na escala 1:2.500.000. Brasília: CPRM. CD-ROM 3.

Dorman L. \& Lewis B. 1970. Experimental isostasy, 1, Theory of the determination of the Earth's isostatic response to a concentrated load. Journal of Geophysical Research, 75:3357-3365.

Dourado J.C. 2004. Estruturação crustal da região de Rio Claro através da sismologia. PhD Thesis, Universidade Estadual Paulista, Rio Claro, $104 \mathrm{p}$

Fairhead J.D., Green C.M., Blitzkow D. 2003. The use of GPS in gravity surveys. The Leading Edge, 22:954-959.

Fairhead J.D. \& Odegard M.E. 2002. Advances in gravity survey resolution. The Leading Edge, 21:36-37.

Ferreira F.F.J. 1982. Integração de dados aeromagnéticos e geológicos: configuração e evolução tectônica do Arco de Ponta Grossa. MS Dissertation, Instituto de Geociências, Universidade de São Paulo, São Paulo, 169 p.

Ferreira F.J.F., Moraes R.A.V., Ferrari M.P., Viana R.B. 1981. Contribuição ao estudo do Alinhamento Estrutural de Guapiara. In: Simpósio Regional de Geologia, 3., 1981. Atas... p 226-240. v. 1

Fries M. 2008. Estudo dos altos estruturais de Pitanga, Artemis, Pau D'Alho e Jibóia (flanco nordeste da Bacia Sedimentar do Paraná) através dos métodos geofísicos da gravimetria e magnetometria terrestres. PhD Thesis, Universidade Estadual Paulista, Rio Claro, 262 p.

Fulfaro V.J. 1971. A evolução tectônica e paleogeográfica da Bacia Sedimentar do Paraná pelo "Trend surface analysis". Boletim da Escola de Engenharia de São Carlos da USP, 14:1-112.

Fulfaro V.J., Gama Jr. E., Soares P.C. 1980. Revisão estratigráfica da Bacia do Paraná. São Paulo, PAULIPETRO, Consórcio IPT/CESP. Relatório 008/80.

Fulfaro V.J., Saad A.R., Santos M.V., Vianna R.B. 1982. Compartimentação e evolução tectônica da Bacia do Paraná. Revista Brasileira de Geociências, 12(4):233-256.

GM-SYS. 2000. Gravity magnetic modeling software user's guide for version 4.6. Corvallis, Northwest geophysical associates, Inc., $100 \mathrm{p}$.

Hasuiu Y., Haralyi N.L.E., Campanha V.A., Hamza V.M., Galli V.A., Frangipani A., Puleghini F.P. 1989. Compartimentação estrutural e evolução tectônica do Estado de São Paulo. São Paulo, IPT. Relatório 27394 - Pró-Minério.

Hildenbrand T.G. \& Kucks R.P. 1983. Regional magnetic and gravity features of the Gibson Dome area surrounding region, Paradox Basin Utah: a preliminary report: US Geological Survey Open-File Report 83 - 359. Denver, Colorado: US Dept. of the Interior, Geological Survey.

IPT - Instituto de Pesquisas Tecnológicas do Estado de São Paulo. 1980. Prospecção geofísica (sondagens elétricas verticais e magnetometria) em apoio aos estudos geológicos na região de São Pedro e Piracicaba - bloco 47, Divisão de Minas e Geologia Aplicada. São Paulo, IPT. Relatório IPT n. 14.481. 55 p.

IPT - Instituto de Pesquisas Tecnológicas do Estado de São Paulo. 1981. Mapa Geológico do Estado de São Paulo, escala 1:500.000. São Paulo, Divisão de Minas e Geologia Aplicada.
Landim P.M.B., Soares P.C. Gama Jr. E. 1980. Estratigrafia do nordeste da Bacia do Rio Paraná. Rio Claro: IPT/UNESP. 45 p. Curso de Especialização.

Milani E.J. 1997. Evolução tectono-estratigráfica da Bacia do Paraná e seu relacionamento com a geodinâmica fanerozóica do Gondwana sul - ocidental. PhD Thesis, Universidade Federal do Rio Grande do Sul, Porto Alegre, $255 \mathrm{p}$.

Milani E.J. \& Ramos V.A 1998. Orogenias Paleozóicas no Domínio Sul-Ocidental do Gandwana e os ciclos de subsidência da Bacia do Paraná. Revista Brasileira de Geociências, 28(4):473-484

Morales N., Perinotto J.A.J., D’affonseca F.M. 1997. Evidências de tectônica distensiva sindeposicional à Formação Tatuí na região de Limeira S.P. In: Simpósio de Geologia do Sudeste, 5., 1997. Anais..., p. 60-61.

Ofoegbu C.O. \& Hein K. 1991. Analysis of magnetic data over part of the younger granite Granite Province of Nigeria. Pure Applied Geophysics, 136:173-189.

Paulipetro - Consórcio CESP/IPT. 1981. Metodologia da Paulipetro para prospecção geofísica na Bacia do Paraná. In: Seminário sobre Exploração do Petróleo no Brasil, Rio de Janeiro.

Quintas M.C.L. 1994. O embasamento da Bacia do Paraná reconstrução geofísica de seu arcabouço. PhD Thesis, Universidade de São Paulo, São Paulo, 218 p.

Riccomini C. 1989. O Rift Continental do sudeste do Brasil. PhD Thesis, Universidade de São Paulo, São Paulo, 256 p.

Riccomini C. 1992. Estilos estruturais da região do Domo de Pitanga, Bacia do Paraná, SP. Boletim do Instituto de Geociências da USP, 12.93-94.

Riccomini C. 1995. Tectonismo gerador e deformador dos depósitos sedimentares pós-gondwânicos da porção centro-oriental do Estado de São Paulo e áreas vizinhas. Thesis (livre docência), Universidade de São Paulo, São Paulo. 100 p.

Riccomini C. 1997. Arcabouço estrutural e aspectos do tectonismo gerador e deformador da Bacia Bauru no Estado de São Paulo. Revista Brasileira de Geociências, 27(2):153-162.

Rostirola S.R., Assine M.L., Fernandes L.A., Arthur P.C. 2002. Reativação de paleolineamentos durante a evolução da Bacia do Paraná exemplo do Alto Estrutural de Guatiguá. Revista Brasileira de Geociências, 30(4):639-648.

Shuey R., Schellinger D., Tripp A., Alley L. 1977. Curie depth determination from aeromagnetic spectra. Geophysical Journal of the Royal Astronomical Society, 50:75-101.

Soares P.C. 1971. Elementos estruturais da parte nordeste da Bacia do Paraná: classificação e gênese. In: Congresso Brasileiro de Geologia, 1971. Anais... v. 1, p. 107-121.

Soares P.C. 1973. O mesozóico Gondwânico no Estado de São Paulo. PhD Thesis, Faculdade de Filosofia, Ciências e Letras de Rio Claro, Rio Claro, $152 \mathrm{p}$

Soares P.C. 1974. Elementos estruturais da parte nordeste da Bacia do Paraná: classificação e gênese. In: Congresso Brasileiro de Geologia, 1974. Anais... v. 30, p. 107-121.

Soares P.C. 1991. Tectônica Sinsedimentar cíclica na Bacia do Paraná - Controles. Thesis (concurso ao cargo de professor titular), Universidade Federal do Paraná, Curitiba, 131 p.

Soares P.C., Barcellos P.E., Csordas S.M. 1982. Lineamentos em imagens de landsat e radar e suas implicações no conhecimento tectônico da Bacia do Paraná. In: Simpósio Brasileiro de Sensoriamento Remoto, 1982. Anais... p. 143-167. 
Soares P.C. \& Landim P.M.B. 1973. Aspectos Regionais da Bacia do Paraná no seu flanco nordeste. In: Congresso Brasileiro de Geologia, 1973. Anais... v. 1, p. 243-256.

Sousa M.O.L. 1997. Caracterização Estrutural do Domo de Pitanga SP. MS Dissertation, Universidade Estadual Paulista "Júlio de Mesquita Filho", Rio Claro, 116 p.

Sousa M.O.L. 2002. Evolução Tectônica dos Altos Estruturais de Pitanga, Ártemis, Pau D’ Alho, e Jibóia - Centro de Estado de São Paulo. PhD Thesis, Universidade Estadual Paulista, Rio Claro, 206 p.

Souza Filho E.E. 1983. Tectônica da região de Rio Claro-Piracicaba, Domo de Pitanga. In: Simpósio Regional de Geologia, 1983. Atas... p. 191-196.

Spector A. \& Grant F.S. 1970. Statistical models for interpreting aeromagnetic data. Geophysics, 35:293-302.

Talwani M., Heirtzler J.R. 1964. Computation of magnetic anomalies caused by two-dimensional bodies of arbitrary shape In: Parks G.A. (ed.). Computers in the mineral industrie. Part I, 9, San Francisco, Stanford University Publications, Geological Sciences. p. 464-480.

Talwani M., Worzel J.L., Landisman N.M. 1959. Rapid gravity computations for two-dimensional bodies with application to the Mendocino submarine fracture zone. Journal of Geophysical Research, 64:49-59.

Telford W.M., Geldart L.P., Sheriff R.E. 1990. Applied Geophysics. Cambridge, Cambridge University Press, $2^{\text {nd }}$ edition, $770 \mathrm{p}$.

Tselentis G., Drakopoulos J., Dimitriadias K. 1988. A spectral approach to Moho depths estimation from gravity measurements in Epirus (NW Greece). Journal Physics of the Earth, 36:255-266.

Washburne C.W. 1930. Petroleum Geology of the State of São Paulo. Boletim do Instituto Geográfico e Geológico, 22:272 p.

Zalán P., Wolff S., Conceição J., Vieira I.S., Appi V.T., Zanotto O.A.P. 1987. Tectônica e Sedimentação da Bacia do Paraná. In: Simpósio Sul Brasileiro de Geologia, 1987. Atas..., p. 441-477.

Zalán P.V., Wolff S., Conceição J.C.J., Marques A., Astolfi M.A.M., Vieira I.S., Appi V.T., Zanotto O. 1990. Bacia do Paraná. In: Gabaglia G.P.R., Milani E.J. (eds.), Origem e evolução de bacias sedimentares. Rio de Janeiro, PETROBRAS, p. 135-168.

Available at www.sbgeo.org.br 